\title{
Power plant fuel switching and air quality in a tropical, forested environment
}

\author{
Adan S. S. Medeiros ${ }^{1,2}$, Gisele Calderaro ${ }^{1}$, Patricia C. Guimarães ${ }^{1}$, Mateus R. Magalhaes ${ }^{1}$, Marcos V. B. Morais ${ }^{4}$, \\ Sameh A. A. Rafee ${ }^{4}$, Igor O. Ribeiro ${ }^{1}$, Rita V. Andreoli ${ }^{3}$, Jorge A. Martins ${ }^{5}$, Leila D. Martins ${ }^{6}$, Scot T. Martin ${ }^{7}$, and \\ Rodrigo A. F. Souza ${ }^{3}$ \\ ${ }^{1}$ Post-graduate Program in Climate and Environment, CLIAMB, INPA/UEA, Av. André Araújo, 2936, 69060-001, Manaus, \\ Amazonas, Brazil \\ ${ }^{2}$ Amazonas State University, Center of Superior Studies of Tefé, R. Brasília, 2127, 69470-000, Tefé, Amazonas, Brazil \\ ${ }^{3}$ Amazonas State University, Superior School of Technology, Av Darcy Vargas, 1200, 69065-020, Manaus, Amazonas, Brazil \\ ${ }^{4}$ Post-graduate Program in Environmental Engineering, Federal University of Technology, Av. Dos Pioneiros, 3131, \\ 86047-125, Londrina, Paraná, Brazil \\ ${ }^{5}$ Department of Physics, Federal University of Technology, Av. Dos Pioneiros, 3131, 86047-125, Londrina, Paraná, Brazil \\ ${ }^{6}$ Department of Chemistry, Federal University of Technology, Av. Dos Pioneiros, 3131, 86047-125, Londrina, Paraná, Brazil \\ ${ }^{7}$ School of Engineering and Applied Sciences, Harvard University, 02138, Cambridge, Massachusetts, USA
}

Correspondence to: Scot T. Martin (scot_martin@harvard.edu) and Rodrigo A. F. Souza (souzaraf@gmail.com)

Received: 10 December 2016 - Discussion started: 4 January 2017

Revised: 16 June 2017 - Accepted: 24 June 2017 - Published: 26 July 2017

\begin{abstract}
How a changing energy matrix for electricity production affects air quality is considered for an urban region in a tropical, forested environment. Manaus, the largest city in the central Amazon Basin of Brazil, is in the process of changing its energy matrix for electricity production from fuel oil and diesel to natural gas over an approximately 10year period, with a minor contribution by hydropower. Three scenarios of urban air quality, specifically afternoon ozone concentrations, were simulated using the Weather Research and Forecasting (WRF-Chem) model. The first scenario used fuel oil and diesel for electricity production, which was the reality in 2008. The second scenario was based on the fuel mix from 2014, the most current year for which data were available. The third scenario considered nearly complete use of natural gas for electricity production, which is the anticipated future, possibly for 2018. For each case, inventories of anthropogenic emissions were based on electricity generation, refinery operations, and transportation. Transportation and refinery operations were held constant across the three scenarios to focus on effects of power plant fuel switching in a tropical context. The simulated $\mathrm{NO}_{x}$ and $\mathrm{CO}$ emissions for the urban region decrease by 89 and $55 \%$, respectively, after the complete change in the energy matrix. The results
\end{abstract}

of the simulations indicate that a change to natural gas significantly decreases maximum afternoon ozone concentrations over the population center, reducing ozone by $>70 \%$ for the most polluted days. The sensitivity of ozone concentrations to the fuel switchover is consistent with a $\mathrm{NO}_{x}$ limited regime, as expected for a tropical forest having high emissions of biogenic volatile organic compounds, high water vapor concentrations, and abundant solar radiation. There are key differences in a shifting energy matrix in a tropical, forested environment compared to other world environments. Policies favoring the burning of natural gas in place of fuel oil and diesel have great potential for ozone reduction and improved air quality for growing urban regions located in tropical, forested environments around the world.

\section{Introduction}

The evolution of modern civilization is closely associated with obtaining and distributing energy at a large scale (Price, 1995). Although electricity production for Brazil as a whole is obtained mostly by hydroelectric plants (ANEEL, 2008), in today's Amazon region, constituting the largest tropi- 
cal forest in the world (Behling et al., 2001), electricity is largely produced by fossil fuel power plants (ELETROBRAS, 2016). Sulfur-laden oil and diesel are the historical fuels. The Amazon region is of vital importance for the functioning of both regional ecosystems and climate (Fisch et al., 1998; Nobre et al., 2016). Topics for research in recent years have included the relationship between the biosphere and the atmosphere in the Amazon (Fan et al., 1990; Stark et al., 2015); the impacts of land use change (Dickinson and Kennedy, 1992; Fearnside, 2003; Paula et al., 2014; WertzKanounnikoff et al., 2016); and the consequences of urbanization, population growth, and increased anthropogenic emissions to the composition of the atmosphere (Shukla et al., 1990; Potter et al., 2001; Wright, 2005; Malhi et al., 2008; Martin et al., 2016).

The population of northern Brazil has grown rapidly in recent decades. In the last 50 years (1960-2010), the urban population of the region increased from about 1 to 11 million, while the urban population of Brazil grew from 32 to 160 million in the same period (IBGE, 2016). This growth in the northern region is linked to public policies to increase development, exemplified by the establishment in 1967 of a free-trade zone in Manaus in central Amazonia. In 2014, this concession was extended until 2073 (Queiroz, 2014), suggesting continued rapid population growth for the region in the coming decades. Continued growth related to electricity production can be expected in support of the population and industry.

In this context Manaus, Amazonas, is the financial, corporate, and economic center of northern Brazil. It has a population of 2 million and is the seventh-largest city in Brazil (IBGE, 2015). The population in recent time has increased nearly every year by 50000 persons due to internal migration motivated by the large industrial district, an area that receives tax exemption from the government. Population growth continually increases the demand for land, energy, and power, leading to the loss of adjacent forest and the degradation of air quality in the region (Cropper and Griffiths, 1994). The installed base for electricity production has increased by around $10 \%$ annually in Manaus over the last 2 decades.

In 2009 , a $650 \mathrm{~km}$ natural gas pipeline was inaugurated, linking a region of natural gas production in Urucu, Amazonas, to Manaus (Soares et al., 2014). From an operational and cost point of view, an uninterrupted fuel supply and the direct distribution from the source to the end user, such as provided by the natural gas pipeline, significantly reduced both costs and related emissions for the transport of fuels on trucks and ships (Neiva and Gama, 2010). With the supply of natural gas, the power plants of Manaus have been adjusting to the economic conditions of the changed fuel mix, replacing fuel oil and diesel with natural gas over an approximately 10 -year period. Although the historical change was not motivated at the policy level by environmental drivers, the change nonetheless represents a unique opportunity to evaluate how fuel switching can affect air quality, especially in regard to little-studied tropical forest environments.

Emission factors of pollutants and pollutant precursors differ greatly between fuel oil and diesel on the one hand and natural gas on the other, and these emissions affect regional air quality and human health (Vitousek et al., 1997; Holgate et al., 1999). Air pollution can lead to arterial vasoconstriction (Brook et al., 2002), cytogenetic damage in lymphocytes (Holland et al., 2015), chronic obstructive pulmonary disease (COPD) (Schikowski et al., 2014), and asthma immunopathogenesis (Alexis and Carlsten, 2014). The World Health Organization (WHO) provides recommendations on the thresholds of pollutant concentrations - such as ozone, particulate matter, nitrogen dioxide, and sulfuric dioxide above which human health is adversely affected (WHO, 2006).

Ozone is the criteria air quality pollutant considered herein. The interactions among oxides of nitrogen $\left(\mathrm{NO}_{x}\right)$, volatile organic compounds (VOCs), water vapor, and sunlight combine to produce ozone (Seinfeld and Pandis, 2006). It is a secondary pollutant whose production depends on the prevailing chemistry and meteorological conditions. Daily surface concentrations are maximum in the afternoon because the production rate depends on sunlight. The ratio of $\mathrm{NO}_{x}$ to VOC concentrations is of fundamental importance for the production rate of ozone. In tropical, forested Amazonia, biogenic volatile organic compounds are emitted in great quantities from the forest and are naturally abundant, while $\mathrm{NO}_{x}$ emissions are primarily from the soil, and atmospheric concentrations remain low (Fehsenfeld et al., 1992; Kesselmeier and Staudt, 1999; Karl et al., 2007; Jardine et al., 2015; Jokinen et al., 2015; Yáñez-Serrano et al., 2015; Liu et al., 2016). The pristine forest environment produces maximum afternoon surface ozone concentrations of 10 to $20 \mathrm{ppb}$ in the wet season (Kirchhoff, 1988). Human activities can significantly elevate $\mathrm{NO}_{x}$ concentrations above background concentrations (Delmas et al., 1997; Lamarque et al., 2010; Daskalakis et al., 2016). For this reason, economic activities and policy decisions that affect $\mathrm{NO}_{x}$ emissions deserve special attention in the context of Amazonia. A quantitative understanding of how an anthropogenically perturbed VOC: $\mathrm{NO}_{x}$ ratio affects ozone production in this region is, however, not trivial. Compared to temperate urban regions that have been studied in greater detail for ozone production, the tropical region has more intense solar radiation and higher water vapor concentrations (Kuhn et al., 2010). Regional modeling is an important approach for understanding the linked effects (Potter et al., 2001; Isaksen et al., 2009).

The study herein evaluates how a changing energy matrix in a tropical, forested environment affects urban pollutant concentrations. It investigates how a shift in the energy matrix over a 10-year period affects regional air quality. For that purpose, ozone is chosen for detailed study because of the concern for human health and the susceptibility of its secondary production to factors at play in a forest environ- 
ment. Manaus is chosen for study because of its location in the tropical forest, its size, and its shifting energy matrix. A large international experiment, Observations and Modeling of the Green Ocean Amazon (GoAmazon2014/5), was also carried out over 2 years in 2014 and 2015 in the Manaus region (Martin et al., 2016), including aircraft flights (Martin et al., 2017). The present study provides interpretative context for the 2-year experiment of GoAmazon2014/5. For case A of the present study, fuel oil and diesel are used for electricity production, which was the reality in 2008. The Urucu pipeline began initial, albeit small, shipments of natural gas in 2010, with increasing amounts every year thereafter. By 2014, natural gas had increased from 0 to $65 \%$ of the energy matrix for electricity production. Case B corresponds to the energy matrix of 2014. Case C considers the nearly complete use of natural gas for electricity production, which is the planned future, possibly for 2018. For each case, inventories of anthropogenic emissions are based on electricity generation, refining operations, and transportation. Transportation and refinery operations are held constant across the three scenarios to focus on effects of power plant fuel switching in a tropical context. The study herein focuses on the wet season because regional anthropogenic activities of the urban environment are easily compared to background conditions. The dry season is more complicated because of continental biomass burning that produces additional ozone precursors (Martin et al., 2010).

\section{Model description}

\subsection{WRF-Chem}

Simulations were carried out using the Weather Research and Forecasting model fully coupled to a chemical module (WRF-Chem version 3.6.1) (Grell et al., 2005). The WRF configuration included the treatment of Lin et al. (1983) for cloud microphysics, MM5 for surface layer (Grell et al., 1994), Noah for land surface (Chen et al., 1997), Yonsei University for boundary layer (Hong et al., 2006), Goddard for short-wave radiation (Chou and Suarez, 1999), the Rapid Radiative Transfer Model for long-wave radiation (Mlawer et al., 1997), and Grell and Freitas (2014) for cumulus clouds. The modeling approach with these parametrizations has been studied (Ying et al., 2009; Misenis and Zhang, 2010; Gupta and Mohan, 2015), showing adequate sensitivity to capture the effects of a changing emissions inventory.

Two nested domains were employed (Fig. 1). An outer domain (denoted as "Domain 1" in inset figure) had a resolution of $10 \mathrm{~km}$ and a dimension of $1050 \mathrm{~km} \times 800 \mathrm{~km}$. This domain employed reanalysis data from the Climate Forecast System Reanalysis (CFSv2). An inner domain ("Domain 2", represented in the full figure) had a resolution of $2 \mathrm{~km}$ and a dimension of $302 \mathrm{~km} \times 232 \mathrm{~km}$. This domain included the study area for which dynamic chemical transport modeling

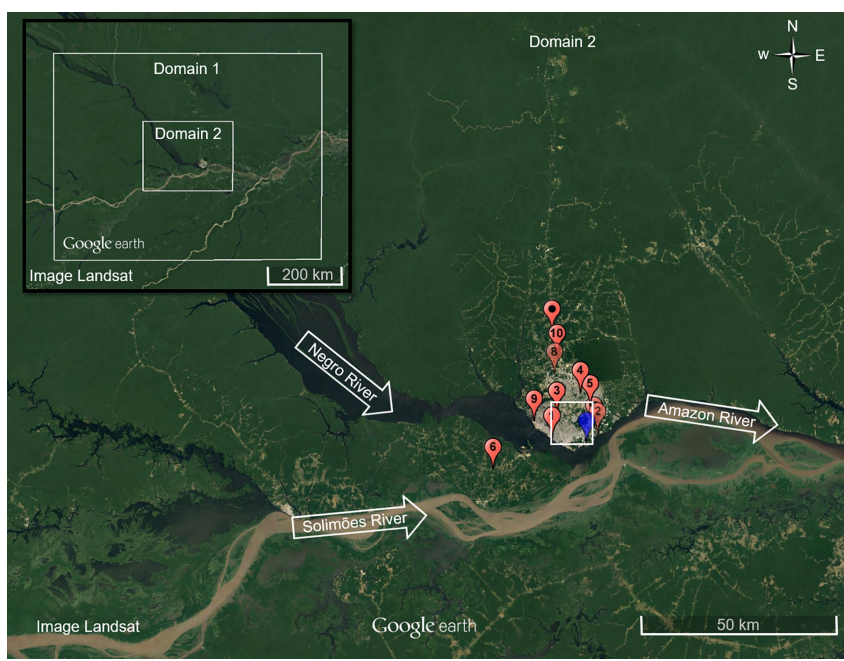

Figure 1. Satellite image of the land cover of the study region. Manaus - located at $3.1^{\circ} \mathrm{S}, 60.0^{\circ} \mathrm{W}-$ is visible in the center. Power plants (red markers) and an oil refinery (blue marker) are indicated (cf. Table 2). The white box represents the region of $10 \mathrm{~km} \times 10 \mathrm{~km}$ that is used for the analyses in Figs. 2, 3 (black box), and 4. The Solimões River, running from the west to the east, is visible in brown. This river has turbid waters laden with sediment. The $\mathrm{Ne}$ gro River is a main tributary. It is visible in black, running from the northwest to southeast. The named Amazon River (Portuguese) is the confluence of these two flows near Manaus. In the top left of the figure, the two grids used in the modeling are shown. The outer grid has corners of $5.10^{\circ} \mathrm{S}, 63.14^{\circ} \mathrm{W}$ and $0.73^{\circ} \mathrm{S}, 57.48^{\circ} \mathrm{W}$. The inner grid has corners of $3.63^{\circ} \mathrm{S}, 61.26^{\circ} \mathrm{W}$ and $2.16^{\circ} \mathrm{S}, 59.36^{\circ} \mathrm{W}$. The latitude-longitude corners of the main panel are the same as the inner grid.

was simulated. The urban region of Manaus is seen in white in the land cover image of domain 2. Domain 2 had initial and boundary conditions based on interpolation of domain 1 . The grid center was the same for both domains $\left(2.908^{\circ} \mathrm{S}\right.$, $\left.60.319^{\circ} \mathrm{W}\right)$. The model spin-up time was $24 \mathrm{~h}$, followed by $72 \mathrm{~h}$ of simulation. In this way, 10 simulations covered a 1-month period. This approach balanced between computational time and numerical diffusion.

Meteorological fields were obtained from reanalysis data of the National Center for Environmental Prediction (NCEP) at a spatial resolution of $0.5^{\circ} \times 0.5^{\circ}$ and a time resolution of $6 \mathrm{~h}$ from 1 to 28 February 2014. NCEP data are based on the Climate Forecast System Reanalysis (Saha et al., 2011). Land cover was based on data from the Moderate Resolution Imaging Spectroradiometer (MODIS) (Rafee et al., 2015). The climatology has differences between dry and wet seasons, with minimum values of monthly precipitation reached in August $(47 \mathrm{~mm})$ and maximum values found in March (335 mm) (Ramos et al., 2009). The month considered herein (February) has a climatological average of $290 \mathrm{~mm}$. For February 2014, there was a deficit of $21.5 \%$ for meteorological stations in Manaus (Fig. S1 in the Supplement), 


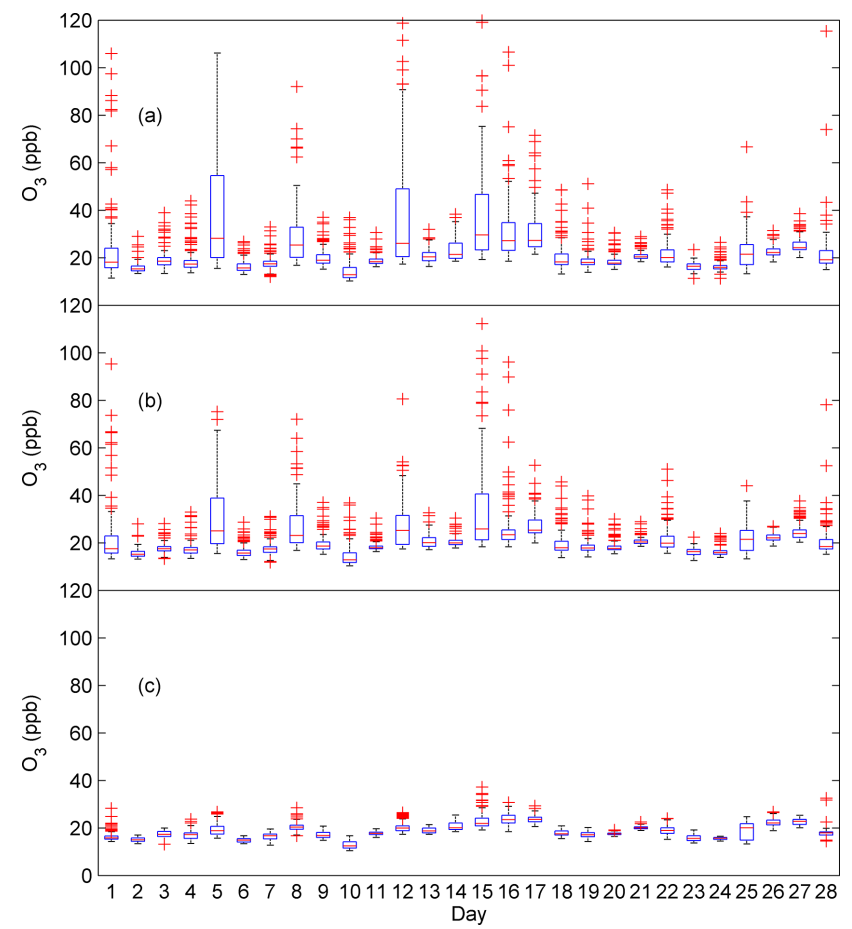

Figure 2. Box-and-whisker plot of near-surface ozone concentrations for historical emissions (case A), present-day emissions (case B), and planned future emissions (case C). On each day of the simulated month, the time period for the statistical analysis corresponds to 12:00 and 16:00 local time. The region of areal averaging is $10 \mathrm{~km} \times 10 \mathrm{~km}$, centered on $3.1^{\circ} \mathrm{S}, 60.0^{\circ} \mathrm{W}$ (boxed regions of Figs. 1 and 3). The bottom and top of the blue boxes correspond to the first and third quartiles, respectively. The red line inside the box is the median. The whiskers represent the full range of values excluding outliers. The red crosses show outliers, as defined by more than 1.5 times the interquartile range.

with high precipitation above $20 \mathrm{~mm}$ on 5 days. The February deficit might correlate with a shifted position of the Bolivian high to the west of its normal position. This anticyclonic circulation at high atmosphere is associated with latent heat release during austral summer (Silva Dias et al., 1983; Jones and Horel, 1990). By comparison, the Intertropical Convergence Zone (ITCZ) was at its climatological position in February 2014, and exceptional events related to the South Atlantic Convergence Zone (SACZ) or other frontal systems in the region were absent (CPTEC-INPE, 2014).

For the chemical part of the model, anthropogenic and biogenic emissions of gases were considered (described in Sect. 2.2). For domain 2, the widely used Regional Acid Deposition Model Version 2 (RADM2) served as the chemical mechanism. It included 63 chemical species, 21 photolysis reactions, and 124 chemical reactions (Stockwell et al., 1990; Chang, 1991). Initial and boundary conditions for trace gases in domain 2 were obtained from MOZART-4, an offline chemical transport model that has 85 chemical species,
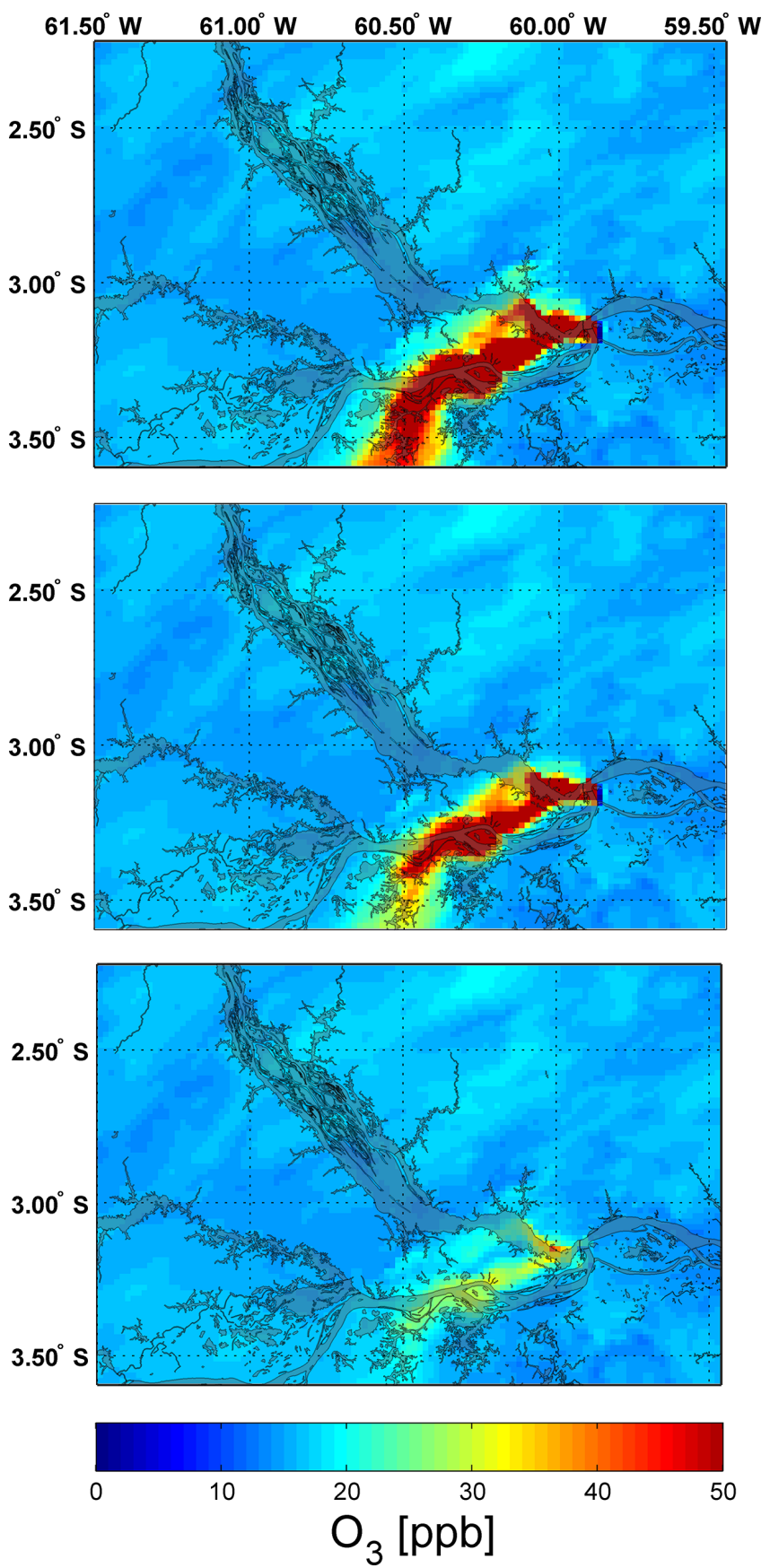

Figure 3. Maps of near-surface ozone concentrations for historical emissions (case A), present-day emissions (case B), and planned future emissions (case C). Ozone concentrations correspond to 15:00 (local time) near the surface for the meteorology of 1 February 2014. The local river system is shown in the background. The black box, centered over the population center of Manaus, represents the averaging area used in the box-and-whisker plots of Figs. 2 and 4.

12 aerosol compounds, 39 photolysis reactions, and 157 gasphase reactions (Emmons et al., 2010). 
Table 1. Manaus transportation fleet. Percent composition, daily travel distance, and emission factors are listed for different vehicle types in 2014 (ANP, 2014).

\begin{tabular}{lrrrr}
\hline Type (fuel) & $\%$ & $\begin{array}{r}\text { Daily travel } \\
\text { distance }(\mathrm{km})\end{array}$ & $\begin{array}{r}\mathrm{CO} \\
\left(\mathrm{g} \mathrm{km}^{-1}\right)\end{array}$ & $\begin{array}{r}\mathrm{NO} \\
\left(\mathrm{g} \mathrm{km}^{-1}\right)\end{array}$ \\
\hline Light vehicles (gasoline) & 21.6 & 48.2 & 5.43 & 0.34 \\
Light vehicles (ethanol) & 2.5 & 48.2 & 12.0 & 1.12 \\
Light vehicles (flex) & 42.1 & 48.2 & 5.13 & 0.32 \\
Urban bus (diesel) & 1.9 & 208.3 & 4.95 & 9.81 \\
Trucks (diesel) & 3.2 & 304.7 & 4.95 & 9.81 \\
Pickup trucks (diesel) & 3.9 & 49.9 & 4.95 & 9.81 \\
Motorcycles (gasoline) & 24.8 & 27.9 & 9.15 & 0.13 \\
\hline
\end{tabular}

\subsection{Emissions}

Forest, vehicle, power plant, and refinery emissions were considered. Biogenic emissions from the forest were based on the Model of Emissions of Gases and Aerosols from Nature (MEGAN, version 2.1) (Guenther et al., 2012). MEGAN varies emissions, taking into account the type of vegetation, the seasonality based on temperature and leaf area index (LAI), the intensity of incident light, and the soil moisture. It considers 150 different compounds. Approximate biogenic emissions for domain 2 were $50 \%$ as isoprene; $30 \%$ as methanol, ethanol, acetaldehyde, acetone, $\alpha$-pinene, $\beta$-pinene, $t$ - $\beta$-ocimene, limonene, ethane, and propene; $17 \%$ as another 20 compounds (mostly terpenoids); and $3 \%$ as another 100 compounds. During the wet season, regional contributions by biomass burning to ozone precursors are considered negligible (Martin et al., 2016).

For vehicle emissions, a vehicle count for Manaus of 600000 was considered (DENATRAN, 2014). The breakdown of vehicle by type, daily travel distances, and emission factors is listed in Table 1 (ANP, 2014). The Manaus fleet has an average age of 5 years. This relatively young age can be attributed to the timing of rapid urban growth coupled to a vast increase in vehicle ownership during an economic expansion period from 2009 to 2015. The methodology of Martins et al. (2010) was used to distribute the vehicle emissions spatially based on nighttime light intensity observations of the Defense Meteorological Satellite Program Operational Linescan System (DMSP-OLS). These observations were assumed to correlate with overall daily patterns of vehicle traffic. Additional information about this methodology is described in Andrade et al. (2015)

For stationary sources related to electricity production, a survey of the locations of power plants in the Manaus region was conducted. Although the city of Manaus has a large industrial park, these industries mostly produce electronic products and burn little fuel directly. Instead, power plants and a large refinery are major emitters. The data of installed capacity, generated electricity, and fuel used were obtained for each plant (Table 2). The locations of these power plants are shown in Fig. 1. The emission factors for electricity pro- duction by fuel type were based on the database of the US Environmental Protection Agency (EPA) using the median value of the emission factors (Table 3 ). The fuel consumption factor for electricity production is also listed in Table 3 (ELETROBRAS, personal communication, 2014). Another major source of pollution in the region was the Isaac Sabbá Refinery, with the capacity to process $7.3 \times 10^{6} \mathrm{~L}$ of oil per day (PETROBRAS, 2016). The emission factors of refinery operations are listed in Table 3 (DeLuchi, 1993)

\subsection{Scenarios}

Simulations were performed to evaluate ozone concentrations for three different scenarios. The first scenario (case A) was based on emissions of historical Manaus before the gradual process of fuel switching began in 2010. It corresponded to an energy matrix of $100 \%$ oil or diesel for electricity production. Because a gradual change in the energy matrix took place, the second scenario (case B) considered the mix of oil, diesel, and natural gas used in 2014 for electricity production. In 2014, $65 \%$ of the power was generated by natural gas and the remaining $35 \%$ by oil or diesel (ELETROBRAS, personal communication, 2014). The third scenario (case C) used an energy matrix of $100 \%$ natural gas, removing all oil and diesel from electricity production in Manaus. This scenario represents the anticipated situation for the Manaus region within the next several years. Table 2 lists the fuel mix of each case. All three scenarios also include a baseline contribution of $24 \%$ by regional hydropower. For the Manaus region, the power plants generate energy uninterruptedly at full load throughout the year, with contractual arrangements with industry to idle when residential demand increases.

In order to compare only the effects of the change in the type of fuel used, the same matrix of power plants was used for the three scenarios. Although the combined capacity of electricity production increased in recent years following the population and energy demand growth, this change was omitted so the comparative study of the effects of fuel type on air quality could be isolated. Likewise, vehicle emissions were held constant for the three fuel scenarios considered herein to focus on effects of power plant fuel switching in a tropical 


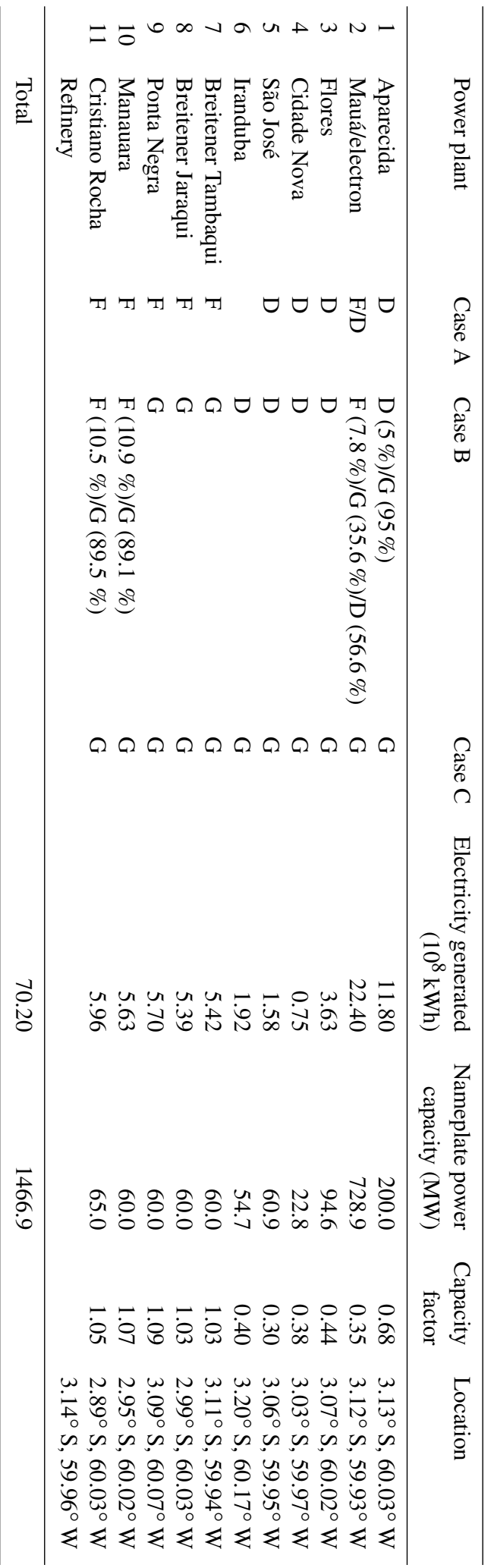

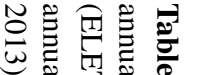

\section{Results and discussion}

Figure 2 shows a box-and-whisker plot of ozone concentrations for all afternoons for each case. The time period of 12:00 to 16:00 (local time) was selected for analysis because it represents the maximum ozone concentration, which is fundamentally linked to photochemistry. For the statistical analysis of Fig. 2, an area of $10 \mathrm{~km} \times 10 \mathrm{~km}$ centered on Manaus was taken to assess ozone concentrations in the populated urban area. The black box in Fig. 3 represents this region. The analysis represented in Fig. 2 shows that within a single case ozone concentrations had large differences throughout the simulated month. These day-to-day differences arose largely because of variability in cloudiness and other meteorological components of the simulation. Some days were sunny, favoring the photochemical process of ozone formation, whereas other days were overcast or rainy.

The variability in ozone concentrations apparent in Fig. 2 among cases A, B, and C arose from differences in the energy matrix for electricity production. A partial shift from diesel and oil to natural gas (i.e., cases A and B) did not greatly shift ozone concentrations, on either polluted or clean days. A complete shift to natural gas (i.e., case $\mathrm{C}$ ), however, considerably reduced ozone concentrations in the urban region. Maximum afternoon ozone concentrations on fair-weather days decreased by more than $70 \%$ (e.g., 110 to $30 \mathrm{ppb}$ ) for the three most polluted days of the simulated month, which occurred on fair-weather days. On poor-weather days, the additional pollution from Manaus contributed to small or negligible additional ozone production. 
Table 3. Emission factors of $\mathrm{CO}$ and $\mathrm{NO}_{x}$ for consumption of fuel oil, diesel, and natural gas in electricity production and refinery operations, obtained as median values from the US EPA (1998) (DeLuchi, 1993). The fuel consumption factor for electricity production is also listed (ELETROBRAS, personal communication, 2014).

\begin{tabular}{lrrrr}
\hline & $\begin{array}{r}\text { Fuel oil } \\
\left(\mathrm{g} \mathrm{L}^{-1}\right)\end{array}$ & $\begin{array}{r}\text { Diesel } \\
\left(\mathrm{g} \mathrm{L}^{-1}\right)\end{array}$ & $\begin{array}{r}\text { Natural gas } \\
\left(\mathrm{g} \mathrm{m}^{-3}\right)\end{array}$ & $\begin{array}{r}\text { Refinery } \\
\left(\mathrm{g} \mathrm{L}^{-1}\right)\end{array}$ \\
\hline $\mathrm{CO}$ & 0.60 & 3.65 & 0.97 & 0.45 \\
$\mathrm{NO}_{x}$ & 3.90 & 36.20 & 2.50 & 0.56 \\
Fuel consumption & $0.29\left(\mathrm{~L} \mathrm{kWh}^{-1}\right)$ & $0.38\left(\mathrm{~L} \mathrm{kWh}^{-1}\right)$ & $0.25\left(\mathrm{~m}^{3} \mathrm{kWh}^{-1}\right)$ & \\
\hline
\end{tabular}

Table 4. Emissions of carbon monoxide $(\mathrm{CO})$ and nitrogen oxides $\left(\mathrm{NO}_{x}\right)$ by vehicles, power plants, and refinery. Values are shown for historical emissions (case A), present-day emissions (case B), and planned future emissions (case C). Values are based on pre-processing chemistry emissions as described in the Methodology section. The percent reduction in total emissions relative to case A is shown in parentheses for cases B and C.

\begin{tabular}{lrrr}
\hline & $\begin{array}{r}\text { Case A } \\
\left(\mathrm{kg} \mathrm{day}^{-1}\right)\end{array}$ & $\begin{array}{r}\text { Case B } \\
\left(\mathrm{kg} \mathrm{day}^{-1}\right)\end{array}$ & $\begin{array}{r}\text { Case C } \\
\left(\mathrm{kg} \mathrm{day}^{-1}\right)\end{array}$ \\
\hline CO (vehicles) & 800 & 800 & 800 \\
$\mathrm{CO}$ (diesel power plants) & 11600 & 6100 & 0 \\
$\mathrm{CO}$ (fuel oil power plants) & 1700 & 200 & 0 \\
$\mathrm{CO}$ (natural gas power plants) & 0 & 3100 & 4600 \\
$\mathrm{CO}$ (refinery) & 1800 & 1800 & 1800 \\
Total CO & 15900 & $12000(-25 \%)$ & $7200(-55 \%)$ \\
$\mathrm{NO}_{x}$ (vehicles) & 400 & 400 & 400 \\
$\mathrm{NO}_{x}$ (diesel power plants) & 115500 & 40700 & 0 \\
$\mathrm{NO}_{x}$ (fuel oil power plants) & 11400 & 1200 & 0 \\
$\mathrm{NO}_{x}$ (natural gas power plants) & 0 & 7800 & 12000 \\
$\mathrm{NO}_{x}$ (refinery) & 2100 & 2100 & 2100 \\
\hline $\mathrm{T}$ (ral NO & 129400 & $52200(-60 \%)$ & $14500(-89 \%)$ \\
\hline
\end{tabular}

A comparison between measurements of $\mathrm{NO}_{x}$ and $\mathrm{O}_{3}$ on board the G-1 aircraft over and downwind of Manaus during GoAmazon2014/5 and simulation results is presented in Fig. S2 for case B. Figure S2a shows agreement between median and interquartile ranges of observed and simulated $\mathrm{NO}_{x}$ concentrations. These concentrations above the natural regional background arise as primary pollutant in Manaus emissions. Likewise, simulated $\mathrm{O}_{3}$ concentrations also show good agreement with aircraft data (Fig. S2b). Ozone is a secondary pollutant, and the agreement supports the validity of the emission inventory of ozone precursors and the chemical mechanisms used in the simulation. Overall, the comparison shows that the simulations satisfactorily represent average regional afternoon concentrations of $\mathrm{NO}_{x}$ and $\mathrm{O}_{3}$. A companion study by Abou Rafee et al. (2017) focuses on the comparison of simulated and measured pollutant concentrations for GoAmazon2014/5.

Figure 3 shows examples of the spatial distribution of ozone concentration for each of cases A, B, and C for the single afternoon of 1 February 2014. Spatial distributions of the mean of afternoon values and their standard deviation over the full month of simulation are shown in Fig. S3. The ozone plume spreads downwind from Manaus carried by the easterlies of the equatorial trade winds, in agreement with observations reported by Kuhn et al. (2010) and Martin et al. $(2016,2017)$. The map shows that the pollution associated with Manaus emissions not only affects local air quality of the urban population but also reaches other regional downwind population centers, such as Careiro, Iranduba, and Manacapuru. The qualitative spatial pattern of the ozone plume is similar among cases $\mathrm{A}, \mathrm{B}$, and $\mathrm{C}$, as explained by the use of identical meteorology. The concentrations, however, have strong differences. From cases A to B, the concentrations inside the plume do not differ greatly, in agreement with the box-and-whisker representation in Fig. 2. For case $\mathrm{C}$, the ozone footprint and concentrations decrease greatly, both for the Manaus urban region and, even more so, for downwind populations, reinforcing the important impact of the fuel switch.

Figure 4 presents a difference analysis between historical practices (i.e., case A) and future plans (i.e., case C) to finalize the foregoing points related to Figs. 2 and 3. The difference analysis represents a shift in the entire energy matrix for electricity production from oil and diesel to that of natural gas. The left panel of Fig. 4 shows the difference map for a single day, corresponding to the plots of Fig. 3. Ozone 

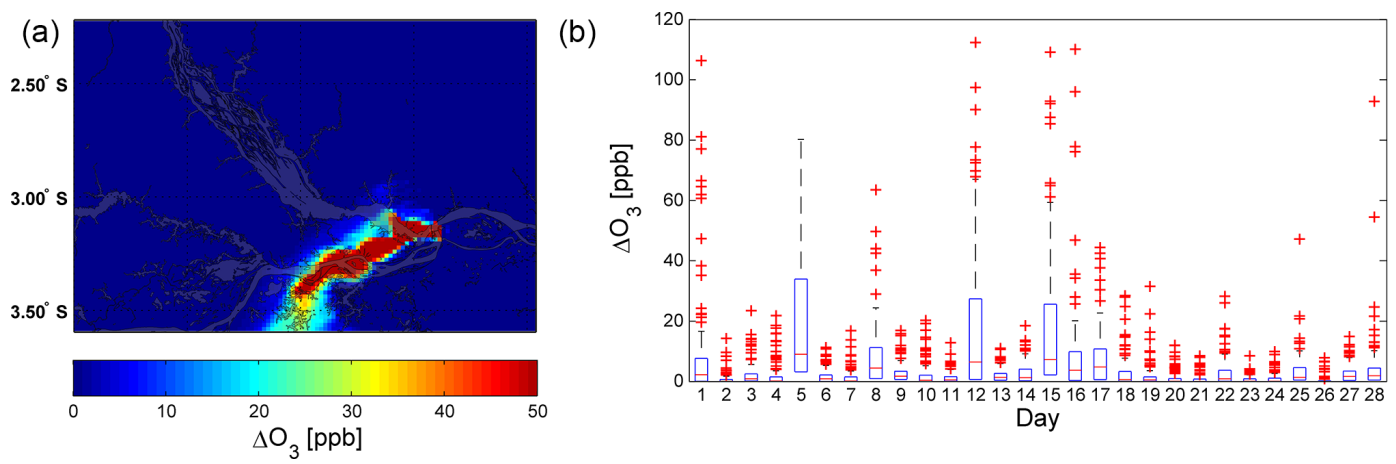

Figure 4. Difference analysis for historical compared to planned future emissions (i.e., case A minus case C). (a) Difference map of ozone concentrations (cf. Fig. 3). (b) Box-and-whisker plot of differences in afternoon ozone concentrations during the 1-month time series (cf. Fig. 2).

concentrations decrease by approximately $50 \mathrm{ppb}$ in the center of the plume. The right panel shows a box-and-whisker plot of difference values in the afternoon period across the month, corresponding to the plots of Fig. 2. Days 1, 5, 8, 12, 15 , and 16 had the highest differences between the two scenarios, indicating that these days were the sunniest and most polluted. For the other days of the month, the median difference approached zero, indicating that these days were overcast or had high levels of convection that brought in clean air. The observed daily rain amounts (Fig. S1) show that the days of highest ozone concentrations corresponded to days of low or no precipitation $(<5 \mathrm{~mm})$. Conversely, the days of highest precipitation $(>20 \mathrm{~mm})$ and cloudiness had nearly background ozone concentrations.

For comparative studies, Collins et al. (1997) investigated the effects of a decrease in $\mathrm{NO}_{x}$ emissions on ozone concentrations over Europe. The study reported that in summer a decrease of $50 \%$ in $\mathrm{NO}_{x}$ emissions resulted in a reduction of ozone by 10 to $20 \%$. A reduction in $\mathrm{NO}_{x}$ emissions in the winter, however, had an opposite effect, increasing the ozone by over $40 \%$. These differing results are explained by the dominance of $\mathrm{NO}_{2}$ as a source of ozone production in the summer but the dominance of $\mathrm{NO}$ as a sink to ozone in the winter. Frost et al. (2006) evaluated the effects of $\mathrm{NO}_{x}$ emissions from power plants on ozone concentrations in the eastern United States. The relationship between emissions reduction and ozone concentrations was complex, depending on upwind $\mathrm{NO}_{x}$ concentrations. For low upwind concentrations, a decrease in $\mathrm{NO}_{x}$ emissions reduced ozone, whereas for high upwind concentrations an equal decrease in $\mathrm{NO}_{x}$ emissions resulted in smaller reductions in ozone or even at times increases in $\mathrm{O}_{3}$. Mena-Carrasco et al. (2012) studied the effects of using natural gas instead of diesel with respect to air quality and human health. The study - carried out for Santiago, Chile, a region of Mediterranean climate - showed that substitution of natural gas for diesel could drastically reduce the emissions and concentrations of particulate matter, which like ozone is another important metric of air quality.
In summary, the results presented herein show that an altered energy matrix significantly influences air quality, as gauged by the maximum afternoon ozone concentration. The relationship between the Manaus emissions and the vast biogenic emissions of the surrounding forest constitutes an important scenario for studying feedback connections in atmospheric chemistry. The large differences between cases A and $\mathrm{C}$ show that the burning of fuel oil and diesel has a dominant role in regional ozone production. Conversely, substitution by natural gas greatly improves the outlook for regional air quality and human health. In this context, even though anthropogenic emissions in the Amazon region are low compared to other regions of the world - such as Mexico City (Molina et al., 2010), São Paulo (Silva Junior and Andrade, 2013), and Los Angeles (Hassler et al., 2016) - the study results of Fig. 4 demonstrate the significant sensitivity of Amazonia to anthropogenic emissions. The results emphasize the high sensitivity of the atmospheric chemistry over the tropical forest to pollution, as amplified by the high solar irradiance and water vapor concentrations in an environment of plentiful biogenic VOC emissions. Specifically, the significant decrease in $\mathrm{NO}_{x}$ emissions from cases $\mathrm{A}$ to $\mathrm{B}$ resulted in no strong differences in ozone concentrations, whereas, conversely, the smaller increase from case C to B resulted in large ozone production. This nonlinear behavior of ozone concentration with respect to pollution is linked to the chemical cycles of the ozone production, more specifically to the domain of $\mathrm{NO}_{x}$ limitation or not (Lin et al., 1988). The results herein suggest that the anticipated complete conversion to natural gas for electricity production should significantly reduce ozone concentration in the Manaus urban region. The GoAmazon2014/5 experiment occurred during 2 years of this 10-year transition in the energy matrix (Martin et al., 2016). Smaller municipalities throughout the Amazon Basin, which is two-thirds the size of the contiguous USA, continue to burn sulfur-laden oil and diesel for electricity production. Further changes in the energy matrix of Amazonia are dependent on continued development of in- 
frastructure for use of natural gas or making connections to the national grid and continued developments in the use of hydropower, even as the population of Amazonia continues to grow rapidly (Domingues, 2003; Tundisi, 2007; ANEEL, 2008).

Data availability. GoAmazon2014/5 data are available in the ARM Climate Research Facility database (https://www.arm.gov/research/ campaigns/amf2014goamazon). Power plant data were obtained from personal communication since they are not available online. These data are mostly used for internal procedures of the power generation company ELETROBRAS. In any case, all data used are available in this manuscript. Vehicle data were obtained from http: //www.denatran.gov.br and http://www.anp.gov.br. Meteorological data were obtained from a network of meteorological stations, available on the EST-UEA Meteorological Instrumentation Laboratory website (https://sites.google.com/a/uea.edu.br/labinstru/home/ rede-de-estacoes).

\section{The Supplement related to this article is available online at https://doi.org/10.5194/acp-17-8987-2017-supplement.}

Competing interests. The authors declare that they have no conflict of interest.

Special issue statement. This article is part of the special issue "Observations and Modeling of the Green Ocean Amazon (GoAmazon2014/5) (ACP/AMT/GI/GMD inter-journal SI)". It does not belong to a conference.

Acknowledgements. We acknowledge support from the Central Office of the Large-Scale Biosphere-Atmosphere Experiment in Amazonia (LBA), the National Institute of Amazonian Research (INPA), the Amazonas State University (UEA), the Financier of Studies and Projects (FINEP), and the Atmospheric System Research (ASR) program of the Office of Biological and Environmental Research, Office of Science, United States Department of Energy (DOE) (grant DE-SC0011115). The first author thanks the Brazilian Coordination for the Improvement of Higher Education Personnel (CAPES) for the grant scholarship, linked to the doctoral program in climate and environment (CLIAMB). The work was conducted under scientific licenses 001030/2012-4 and 400063/2014-0 of the Brazilian National Council for Scientific and Technological Development $(\mathrm{CNPq})$. Funding was received under grant 062.00568/2014 of the Amazonas State Research Foundation (FAPEAM). A FAPEAM Senior Visitor Research Grant is also acknowledged.

Edited by: Maria Assuncao Silva Dias

Reviewed by: Hugo Karan and one anonymous referee

\section{References}

Abou Rafee, S. A., Martins, L. D., Kawashima, A. B., Almeida, D. S., Morais, M. V. B., Souza, R. V. A., Oliveira, M. B. L., Souza, R. A. F., Medeiros, A. S. S., Urbina, V., Freitas, E. D., Martin, S. T., and Martins, J. A.: Contributions of mobile, stationary and biogenic sources to air pollution in the Amazon rainforest: a numerical study with the WRF-Chem model, Atmos. Chem. Phys., 17, 7977-7995, https://doi.org/10.5194/acp17-7977-2017, 2017.

Alexis, N. E. and Carlsten, C.: Interplay of air pollution and asthma immunopathogenesis: a focused review of diesel exhaust and ozone, Int. Immunopharmacol., 23, 347-355, https://doi.org/10.1016/j.intimp.2014.08.009, 2014.

Andrade, M. D. F., Freitas, E. D., Ynoue, R. Y., Todesco, E., Vara, A. V., Ibarra, S., Martins, L. D., Martins, J., and Carvalho, V. S.: Air quality forecasting system for southeastern Brazil, Front. Environmental Science, 3, https://doi.org/10.3389/fenvs.2015.00009, 2015.

ANEEL: Atlas de energia elétrica do Brasil, Brasília, available at: http://www2.aneel.gov.br/arquivos/pdf/atlas3ed.pdf (last access: 8 March 2016), 2008.

ANEEL: Normative Resolution No. 586, 19 November 2013, Brazilian National Agency of Electric Energy, available at: http://www2.aneel.gov.br/aplicacoes/audiencia/arquivo/2013/ 098/resultado/resolucao_normativa_n\%C2\%BA_586,_de_19_ de_novembro_de_2013.pdf (last access: 11 May 2016), 2013.

ANP: National Inventory of Atmospheric Emissions from vehicles of 2013, National Agency of Petroleo, Brazilian Departament of Environment, available at: http://www.anp.gov.br/wwwanp/ images/Emissoes-Atmosfericas-1Inventariodeemissoes.pdf (last access: 13 July 2016), 2014.

Behling, H., Keim, G., Irion, G., Junk, W., and De Mello, J. N.: Holocene environmental changes in the central Amazon Basin inferred from Lago Calado (Brazil), Palaeogeogr. Palaeocl., 173, 87-101, 2001

Brook, R. D., Brook, J. R., Urch, B., Vincent, R., Rajagopalan, S., and Silverman, F.: Inhalation of Fine Particulate Air Pollution and Ozone Causes Acute Arterial Vasoconstriction in Healthy Adults, Circulation, 105, 1534-1536, https://doi.org/10.1161/01.cir.0000013838.94747.64, 2002.

Chang, J. S.: The regional acid deposition model and engineering model, US National Acid Precipitation Assessment Program, Office of the Director, 1991.

Chen, F., Janjić, Z., and Mitchell, K.: Impact of Atmospheric Surface-layer Parameterizations in the new Land-surface Scheme of the NCEP Mesoscale Eta Model, Bound.-Lay. Meteorol., 85, 391-421, https://doi.org/10.1023/a:1000531001463, 1997.

Chou, M.-D. and Suarez, M. J.: A solar radiation parameterization for atmospheric studies, NASA Tech. Memo, 104606, 40, 1999.

Collins, W., Stevenson, D. S., Johnson, C., and Derwent, R.: Tropospheric ozone in a global-scale three-dimensional Lagrangian model and its response to NO x emission controls, J. Atmos. Chem., 26, 223-274, 1997.

CPTEC-INPE: Meteorological Bulletin of the Center for Weather Forecasting and Climatic Studies (CPTEC) of the Brazilian National Institute of Space Research (INPE), available at: http: //climanalise.cptec.inpe.br/ rclimanl/boletim/index0214.shtml (last access: 4 April 2017), 2014. 
Cropper, M. and Griffiths, C.: The interaction of population growth and environmental quality, Am. Econ. Rev., 84, 250-254, 1994.

Daskalakis, N., Tsigaridis, K., Myriokefalitakis, S., Fanourgakis, G. S., and Kanakidou, M.: Large gain in air quality compared to an alternative anthropogenic emissions scenario, Atmos. Chem. Phys., 16, 9771-9784, https://doi.org/10.5194/acp16-9771-2016, 2016.

Delmas, R., Serca, D., and Jambert, C.: Global inventory of $\mathrm{NO}_{x}$ sources, Nutr. Cycl. Agroecosys., 48, 51-60, 1997.

DeLuchi, M. A.: Emissions from the Production, Storage, and Transport of Crude Oil and Gasoline, Air \& Waste, 43, 14861495, https://doi.org/10.1080/1073161X.1993.10467222, 1993.

DENATRAN: available at: http://www.denatran.gov.br/frota2014. htm, last access: 20 January 2014.

Dickinson, R. E. and Kennedy, P.: Impacts on regional climate of Amazon deforestation, Geophys. Res. Lett., 19, 1947-1950, 1992.

Domingues, P. C. M.: A interconexão Elétrica dos Sistemas Isolados da Amazônia ao Sistema Interligado Ncional, available at: https://repositorio.ufsc.br/bitstream/handle/123456789/ 86488/234738.pdf?sequence=1 (last access: 23 April 2016), 2003.

ELETROBRAS: Relatory of Administration and Finances: available at: http://eletrobras.com/pt/ri/DemonstracoesFinanceiras/ Relat\%C3\%B3riodaAdministra\%C3\%A7\%C3\%A3o\%202014. pdf, last access: 13 June 2016.

Emmons, L. K., Walters, S., Hess, P. G., Lamarque, J.-F., Pfister, G. G., Fillmore, D., Granier, C., Guenther, A., Kinnison, D., Laepple, T., Orlando, J., Tie, X., Tyndall, G., Wiedinmyer, C., Baughcum, S. L., and Kloster, S.: Description and evaluation of the Model for Ozone and Related chemical Tracers, version 4 (MOZART-4), Geosci. Model Dev., 3, 43-67, https://doi.org/10.5194/gmd-3-43-2010, 2010.

Fan, S.-M., Wofsy, S. C., Bakwin, P. S., Jacob, D. J., and Fitzjarrald, D. R.: Atmosphere-biosphere exchange of $\mathrm{CO}_{2}$ and $\mathrm{O}_{3}$ in the central Amazon Forest, J. Geophys. Res. Atmos., 95, 1685116864, https://doi.org/10.1029/JD095iD10p16851, 1990.

Fearnside, P. M.: Deforestation Control in Mato Grosso: A New Model for Slowing the Loss of Brazil's Amazon Forest, AMBIO, 32, 343-345, https://doi.org/10.1579/0044-7447-32.5.343, 2003.

Fearnside, P. M.: Brazil's Samuel Dam: Lessons for hydroelectric development policy and the environment in Amazonia, Environ. Manage., 35, 1-19, 2005.

Fehsenfeld, F., Calvert, J., Fall, R., Goldan, P., Guenther, A. B., Hewitt, C. N., Lamb, B., Liu, S., Trainer, M., Westberg, H., and Zimmerman, P.: Emissions of volatile organic compounds from vegetation and the implications for atmospheric chemistry, Global Biogeochem. Cy., 6, 389-430, https://doi.org/10.1029/92GB02125, 1992.

Fisch, G., Marengo, J. A., and Nobre, C. A.: The climate of Amazonia-a review, Acta Amazonica, 28, 101-101, 1998.

Frost, G., McKeen, S., Trainer, M., Ryerson, T., Neuman, J., Roberts, J., Swanson, A., Holloway, J., Sueper, D., and Fortin, T.: Effects of changing power plant $\mathrm{NO}_{x}$ emissions on ozone in the eastern United States: Proof of concept, J. Geophys. Res.Atmos., 111, D12306, https://doi.org/10.1029/2005JD006354, 2006.
Grell, G. A., Dudhia, J., and Stauffer, D. R.: A description of the fifth-generation Penn State/NCAR mesoscale model (MM5), NCAR technical note, https://doi.org/10.5065/D60Z716B, 1994.

Grell, G. A., Peckham, S. E., Schmitz, R., McKeen, S. A., Frost, G., Skamarock, W. C., and Eder, B.: Fully coupled "online" chemistry within the WRF model, Atmos. Environ., 39, 6957-6975, https://doi.org/10.1016/j.atmosenv.2005.04.027, 2005.

Grell, G. A. and Freitas, S. R.: A scale and aerosol aware stochastic convective parameterization for weather and air quality modeling, Atmos. Chem. Phys., 14, 5233-5250, https://doi.org/10.5194/acp-14-5233-2014, 2014.

Guenther, A. B., Jiang, X., Heald, C. L., Sakulyanontvittaya, T., Duhl, T., Emmons, L. K., and Wang, X.: The Model of Emissions of Gases and Aerosols from Nature version 2.1 (MEGAN2.1): an extended and updated framework for modeling biogenic emissions, Geosci. Model Dev., 5, 1471-1492, https://doi.org/10.5194/gmd-5-1471-2012, 2012.

Gupta, M. and Mohan, M.: Validation of WRF/Chem model and sensitivity of chemical mechanisms to ozone simulation over megacity Delhi, Atmos. Environ., 122, 220-229, 2015.

Hassler, B., McDonald, B. C., Frost, G. J., Borbon, A., Carslaw, D. C., Civerolo, K., Granier, C., Monks, P. S., Monks, S., and Parrish, D. D.: Analysis of long-term observations of $\mathrm{NO}_{x}$ and $\mathrm{CO}$ in megacities and application to constraining emissions inventories, Geophys. Res. Lett., 43, 9920-9930, 2016.

Holgate, S. T., Koren, H. S., Samet, J. M., and Maynard, R. L.: Air pollution and health, Academic Press, San Diego, 1999.

Holland, N., Davé, V., Venkat, S., Wong, H., Donde, A., Balmes, J. R., and Arjomandi, M.: Ozone inhalation leads to a dose-dependent increase of cytogenetic damage in human lymphocytes, Environ. Mol. Mutagen., 56, 378-387, https://doi.org/10.1002/em.21921, 2015.

Hong, S.-Y., Noh, Y., and Dudhia, J.: A new vertical diffusion package with an explicit treatment of entrainment processes, Mon. Weather Rev., 134, 2318-2341, 2006.

IBGE: Estimates of the resident population in Brazil and Federative Units, Brazilian Institute of Geography and Statistics, 2015.

IBGE: Brazilian Institute of Geography and Statistics, Demographic census of 1960/2010, available at: http://www. censo2010.ibge.gov.br/sinopse/index.php?dados=8, last access: 5 May 2016.

Isaksen, I. S., Granier, C., Myhre, G., Berntsen, T., Dalsøren, S. B., Gauss, M., Klimont, Z., Benestad, R., Bousquet, P., and Collins, W.: Atmospheric composition change: climate-chemistry interactions, Atmos. Environ., 43, 5138-5192, 2009.

Jardine, K., Yañez-Serrano, A. M., Williams, J., Kunert, N., Jardine, A., Taylor, T., Abrell, L., Artaxo, P., Guenther, A., Hewitt, C. N., House, E., Florentino, A. P., Manzi, A., Higuchi, N., Kesselmeier, J., Behrendt, T., Veres, P. R., Derstroff, B., Fuentes, J. D., Martin, S. T., and Andreae, M. O.: Dimethyl sulfide in the Amazon rain forest, Global Biogeochem. Cy., 29, 19-32, https://doi.org/10.1002/2014GB004969, 2015.

Jokinen, T., Berndt, T., Makkonen, R., Kerminen, V.-M., Junninen, H., Paasonen, P., Stratmann, F., Herrmann, H., Guenther, A. B., Worsnop, D. R., Kulmala, M., Ehn, M., and Sipilä, M.: Production of extremely low volatile organic compounds from biogenic emissions: Measured yields and atmospheric implications, P. Natl. Acad. Sci. USA, 112, 7123-7128, https://doi.org/10.1073/pnas.1423977112, 2015. 
Jones, C. and Horel, J. D.: A circulação da Alta da Bolívia e a atividade convectiva sobre a América do Sul, Revista brasileira de Meteorologia, 5, 379-387, 1990.

Karl, T., Guenther, A., Yokelson, R. J., Greenberg, J., Potosnak, M., Blake, D. R., and Artaxo, P.: The tropical forest and fire emissions experiment: Emission, chemistry, and transport of biogenic volatile organic compounds in the lower atmosphere over Amazonia, J. Geophys. Res.-Atmos., 112, D18302, https://doi.org/10.1029/2007JD008539, 2007.

Kesselmeier, J. and Staudt, M.: Biogenic Volatile Organic Compounds (VOC): An Overview on Emission, Physiology and Ecology, J. Atmos. Chem., 33, 23-88, https://doi.org/10.1023/A:1006127516791, 1999.

Kirchhoff, V. W. J. H.: Surface ozone measurements in Amazonia, J. Geophys. Res.-Atmos., 93, 1469-1476, https://doi.org/10.1029/JD093iD02p01469, 1988.

Kuhn, U., Ganzeveld, L., Thielmann, A., Dindorf, T., Schebeske, G., Welling, M., Sciare, J., Roberts, G., Meixner, F. X., Kesselmeier, J., Lelieveld, J., Kolle, O., Ciccioli, P., Lloyd, J., Trentmann, J., Artaxo, P., and Andreae, M. O.: Impact of Manaus City on the Amazon Green Ocean atmosphere: ozone production, precursor sensitivity and aerosol load, Atmos. Chem. Phys., 10, 9251-9282, https://doi.org/10.5194/acp-10-9251-2010, 2010.

Lamarque, J.-F., Bond, T. C., Eyring, V., Granier, C., Heil, A., Klimont, Z., Lee, D., Liousse, C., Mieville, A., Owen, B., Schultz, M. G., Shindell, D., Smith, S. J., Stehfest, E., Van Aardenne, J., Cooper, O. R., Kainuma, M., Mahowald, N., McConnell, J. R., Naik, V., Riahi, K., and van Vuuren, D. P.: Historical (1850-2000) gridded anthropogenic and biomass burning emissions of reactive gases and aerosols: methodology and application, Atmos. Chem. Phys., 10, 7017-7039, https://doi.org/10.5194/acp-10-7017-2010, 2010.

Lin, X., Trainer, M., and Liu, S. C.: On the nonlinearity of the tropospheric ozone production, J. Geophys. Res.-Atmos., 93, 1587915888, https://doi.org/10.1029/JD093iD12p15879, 1988.

Lin, Y.-L., Farley, R. D., and Orville, H. D.: Bulk parameterization of the snow field in a cloud model, J. Clim. Appl. Meteorol., 22, 1065-1092, 1983.

Liu, Y., Brito, J., Dorris, M. R., Rivera-Rios, J. C., Seco, R., Bates, K. H., Artaxo, P., Duvoisin, S., Keutsch, F. N., and Kim, S.: Isoprene photochemistry over the Amazon rainforest, P. Natl. Acad. Sci. USA, 113, 6125-6130, 2016.

Malhi, Y., Roberts, J. T., Betts, R. A., Killeen, T. J., Li, W., and Nobre, C. A.: Climate change, deforestation, and the fate of the Amazon, Science, 319, 169-172, 2008.

Martin, S. T., Andreae, M. O., Althausen, D., Artaxo, P., Baars, H., Borrmann, S., Chen, Q., Farmer, D. K., Guenther, A., Gunthe, S. S., Jimenez, J. L., Karl, T., Longo, K., Manzi, A., Müller, T., Pauliquevis, T., Petters, M. D., Prenni, A. J., Pöschl, U., Rizzo, L. V., Schneider, J., Smith, J. N., Swietlicki, E., Tota, J., Wang, J., Wiedensohler, A., and Zorn, S. R.: An overview of the Amazonian Aerosol Characterization Experiment 2008 (AMAZE-08), Atmos. Chem. Phys., 10, 1141511438, https://doi.org/10.5194/acp-10-11415-2010, 2010.

Martin, S. T., Artaxo, P., Machado, L. A. T., Manzi, A. O., Souza, R. A. F., Schumacher, C., Wang, J., Andreae, M. O., Barbosa, H. M. J., Fan, J., Fisch, G., Goldstein, A. H., Guenther, A., Jimenez, J. L., Pöschl, U., Silva Dias, M. A., Smith, J. N., and Wendisch, M.: Introduction: Observations and Modeling of the Green Ocean
Amazon (GoAmazon2014/5), Atmos. Chem. Phys., 16, 47854797, https://doi.org/10.5194/acp-16-4785-2016, 2016.

Martin, S. T., Artaxo, P., Machado, L., Manzi, A. O., Souza, R. A. F., Schumacher, C., Wang, J., Biscaro, T., Brito, J., Calheiros, A., Jardine, K., Medeiros, A., Portela, B., Sá, S. S. d., Adachi, K., Aiken, A. C., Albrecht, R., Alexander, L., Andreae, M. O., Barbosa, H. M. J., Buseck, P., Chand, D., Comstock, J. M., Day, D. A., Dubey, M., Fan, J., Fast, J., Fisch, G., Fortner, E., Giangrande, S., Gilles, M., Goldstein, A. H., Guenther, A., Hubbe, J., Jensen, M., Jimenez, J. L., Keutsch, F. N., Kim, S., Kuang, C., Laskin, A., McKinney, K., Mei, F., Miller, M., Nascimento, R., Pauliquevis, T., Pekour, M., Peres, J., Petäjä, T., Pöhlker, C., Pöschl, U., Rizzo, L., Schmid, B., Shilling, J. E., Dias, M. A. S., Smith, J. N., Tomlinson, J. M., Tóta, J., and Wendisch, M.: The Green Ocean Amazon Experiment (GoAmazon2014/5) Observes Pollution Affecting Gases, Aerosols, Clouds, and Rainfall over the Rain Forest, B. Am. Meteorol. Soc., 98, 981-997, https://doi.org/10.1175/bams-d-15-00221.1, 2017.

Martins, J. A., Rocha, C. R. M., Oliveira, M. G. L., Ynoue, R. Y., Andrade, M. F., Freitas, E. D., and Martins, L. D.: Desenvolvimento de inventários de emissão de alta resolução: Intensidades de luzes noturnas e distribuição espacial de veículos, XVI CBMET, 2010.

Mena-Carrasco, M., Oliva, E., Saide, P., Spak, S. N., de la Maza, C., Osses, M., Tolvett, S., Campbell, J. E., Tsao, T. E. C.-C., and Molina, L. T.: Estimating the health benefits from natural gas use in transport and heating in Santiago, Chile, Sci. Total Environ., 429, 257-265, https://doi.org/10.1016/j.scitotenv.2012.04.037, 2012.

Misenis, C. and Zhang, Y.: An examination of sensitivity of WRF/Chem predictions to physical parameterizations, horizontal grid spacing, and nesting options, Atmos. Res., 97, 315-334, 2010.

Mlawer, E. J., Taubman, S. J., Brown, P. D., Iacono, M. J., and Clough, S. A.: Radiative transfer for inhomogeneous atmospheres: RRTM, a validated correlated-k model for the longwave, J. Geophys. Res.-Atmos., 102, 16663-16682, 1997.

Molina, L. T., Madronich, S., Gaffney, J. S., Apel, E., de Foy, B., Fast, J., Ferrare, R., Herndon, S., Jimenez, J. L., Lamb, B., Osornio-Vargas, A. R., Russell, P., Schauer, J. J., Stevens, P. S., Volkamer, R., and Zavala, M.: An overview of the MILAGRO 2006 Campaign: Mexico City emissions and their transport and transformation, Atmos. Chem. Phys., 10, 8697-8760, https://doi.org/10.5194/acp-10-8697-2010, 2010.

Neiva, L. and Gama, L.: The importance of natural gas reforming, INTECH Open Access Publisher, available at: https://cdn intechopen.com/pdfs-wm/11459.pdf (last access 16 February 2016), 2010.

Nobre, C. A., Sampaio, G., Borma, L. S., Castilla-Rubio, J. C., Silva, J. S., and Cardoso, M.: Land-use and climate change risks in the Amazon and the need of a novel sustainable development paradigm, P. Natl. Acad. Sci. USA, 113, 10759-10768, 2016.

Paula, F. S., Rodrigues, J. L. M., Zhou, J., Wu, L., Mueller, R. C., Mirza, B. S., Bohannan, B. J. M., Nüsslein, K., Deng, Y., Tiedje, J. M., and Pellizari, V. H.: Land use change alters functional gene diversity, composition and abundance in Amazon forest soil microbial communities, Mol. Ecol., 23, 2988-2999, https://doi.org/10.1111/mec.12786, 2014. 
PETROBRAS: available at: http://www.petrobras.com. br/pt/nossas-atividades/principais-operacoes/refinarias/ refinaria-isaac-sabba-reman.htm, last access: 20 November 2016.

Potter, C., Klooster, S., Carvalho, C. R., Genovese, V. B., Torregrosa, A., Dungan, J., Bobo, M., and Coughlan, J.: Modeling seasonal and interannual variability in ecosystem carbon cycling for the Brazilian Amazon region, J. Geophys. Res.-Atmos., 106, 10423-10446, 2001.

Price, D.: Energy and human evolution, Popul. Environ., 16, 301319, 1995.

Queiroz, D.: Zona Franca de Manaus está oficialmente prorrogada até 2073, available at: http://site.suframa.gov.br/noticias/ zona-franca-de-manaus-esta-oficialmente-prorrogada-ate-2073 (last access: 15 October 2016), 2014.

Rafee, S. A. A., Kawashima, A. B., de Morais, M. V. B., Urbina, V., Martins, L. D., and Martins, J. A.: Assessing the Impact of Using Different Land Cover Classification in Regional Modeling Studies for the Manaus Area, Brazil, Journal of Geoscience and Environment Protection, 3, 77-82, https://doi.org/10.4236/gep.2015.36013, 2015.

Ramos, A. M., dos Santos, L. A. R., and Fortes, L. T. G.: Normais climatológicas do Brasil, 1961-1990, 2009.

Saha, S., Moorthi, S., Wu, X., Wang, J., Nadiga, S., Tripp, P., Behringer, D., Hou, Y.-T., Chuang, H.-y., Iredell, M., Ek, M., Meng, J., Yang, R., Mendez, M. P., van den Dool, H., Zhang, Q., Wang, W., Chen, M., and Becker, E.: NCEP Climate Forecast System Version 2 (CFSv2) 6-hourly Products, in, Research Data Archive at the National Center for Atmospheric Research, Computational and Information Systems Laboratory, Boulder, CO, 2011.

Schikowski, T., Mills, I. C., Anderson, H. R., Cohen, A., Hansell, A., Kauffmann, F., Krämer, U., Marcon, A., Perez, L., Sunyer, J., Probst-Hensch, N., and Künzli, N.: Ambient air pollution: a cause of COPD?, Eur. Respir. J., 43, 250-263, https://doi.org/10.1183/09031936.00100112, 2014.

Seinfeld, J. H. and Pandis, S. N.: Atmospheric Chemistry and Physics: From air pollution to Climate Change, Second Edn., 2006.

Shukla, J., Nobre, C., and Sellers, P.: Amazon deforestation and climate change, Science, 247, 1322-1325, 1990.

Silva Dias, P. L., Schubert, W. H., and DeMaria, M.: Large-scale response of the tropical atmosphere to transient convection, J. Atmos. Sci., 40, 2689-2707, 1983.
Silva Junior, R. S. D. and Andrade, M. D. F.: Prediction of photochemical pollutants in metropolitan area of São Paulo using air quality model (WRF/CHEM) and the CETESP pollutants emmission inventory, Revista Brasileira de Meteorologia, 28, 105121, 2013.

Soares, P. M., Berni, M. D., and Manduca, P. C.: O petroleo é nosso: avaliação do potencial região do Urucu-AM e principais desafios, RIT-REVISTA INOVAÇÃO TECNOLÓGICA, 4, 64-77, 2014.

Stark, S. C., Enquist, B. J., Saleska, S. R., Leitold, V., Schietti, J., Longo, M., Alves, L. F., Camargo, P. B., and Oliveira, R. C.: Linking canopy leaf area and light environments with tree size distributions to explain Amazon forest demography, Ecol. Lett., 18, 636-645, https://doi.org/10.1111/ele.12440, 2015.

Stockwell, W. R., Middleton, P., Chang, J. S., and Tang, X.: The second generation regional acid deposition model chemical mechanism for regional air quality modeling, J. Geophys. Res.-Atmos., 95, 16343-16367, 1990.

Tundisi, J. G.: Exploração do potencial hidrelétrico da Amazônia, Estudos avançados, 21, 109-117, 2007.

US EPA: Compilation of air pollutant emission factors, volume 1, Staionary point and area source, AP 42, fifth Edn., 1998.

Vitousek, P. M., Mooney, H. A., Lubchenco, J., and Melillo, J. M.: Human domination of Earth's ecosystems, Science, 277, 494499, 1997.

Wertz-Kanounnikoff, S., Kongphan-Apirak, M., and Wunder, S.: Reducing forest emissions in the Amazon Basin: a review of drivers of land-use change and how payments for environmental services (PES) schemes can affect them, Bogor, Indonesia: Center for International Forestry Research (CIFOR), 2016.

WHO: Air quality for particulate matter, ozone, nitrogen dioxide and sulphur dioxide: global update 2005, 2006.

Wright, S. J.: Tropical forests in a changing environment, Trends Ecol. Evol., 20, 553-560, https://doi.org/10.1016/j.tree.2005.07.009, 2005.

Yáñez-Serrano, A. M., Nölscher, A. C., Williams, J., Wolff, S., Alves, E., Martins, G. A., Bourtsoukidis, E., Brito, J., Jardine, K., Artaxo, P., and Kesselmeier, J.: Diel and seasonal changes of biogenic volatile organic compounds within and above an Amazonian rainforest, Atmos. Chem. Phys., 15, 3359-3378, https://doi.org/10.5194/acp-15-3359-2015, 2015.

Ying, Z., Tie, X., and Li, G.: Sensitivity of ozone concentrations to diurnal variations of surface emissions in Mexico City: A WRF/Chem modeling study, Atmos. Environ., 43, 851-859, 2009. 